\title{
Clinical and genetic analysis of 29 Brazilian patients with Huntington's disease-like phenotype
}

\author{
Guilherme Riccioppo Rodrigues ${ }^{1}$, Ruth H. Walker², Benedikt Bader ${ }^{3}$, \\ Adrian Danek ${ }^{3}$, Alexis Brice ${ }^{4}$, Cécile Cazeneuve ${ }^{4}$, Odile Russaouen $^{4}$, \\ Iscia Lopes-Cendes ${ }^{5}$, Wilson Marques Jr. ${ }^{1}$, Vitor Tumas ${ }^{1}$
}

\begin{abstract}
Huntington's disease (HD) is a neurodegenerative disorder characterized by chorea, behavioral disturbances and dementia, caused by a pathological expansion of the CAG trinucleotide in the HTT gene. Several patients have been recognized with the typical HD phenotype without the expected mutation. The objective of this study was to assess the occurrence of diseases such as Huntington's disease-like 2 (HDL2), spinocerebellar ataxia (SCA) 1, SCA2, SCA3, SCA7, dentatorubral-pallidoluysian atrophy (DRPLA) and choreaacanthocytosis (ChAc) among 29 Brazilian patients with a HD-like phenotype. In the group analyzed, we found 3 patients with HDL2 and 2 patients with ChAc. The diagnosis was not reached in $79.3 \%$ of the patients. HDL2 was the main cause of the HD-like phenotype in the group analyzed, and is attributable to the African ancestry of this population. However, the etiology of the disease remains undetermined in the majority of the HD negative patients with HD-like phenotype.
\end{abstract}

Key words: Huntington's disease, Huntington's disease-like, chorea-acanthocytosis, Huntington's disease-like 2.

\section{Correspondence \\ Vitor Tumas \\ Department of Neuroscience and Behaviour Sciences Ribeirão Preto School of Medicine University of São Paulo Campus Universitário 14049-900 Ribeirão Preto SP - Brazil E-mail: tumasv@rnp.fmrp.usp.br}

\begin{abstract}
Support
Dr. Danek serves on the editorial board of Zeitschrift für Gerontoneurologie and Translational Neuroscience; has received speaker honoraria from Merz, Pfizer, Novartis, Janssen-Cilag and Neuro-Update; receives research support as Principal Investigator from Bayerische Forschungsstiftung, German Federal Ministry of Research, Münchner Universitätsgesellschaft, Deutsch-Französische Hochschulstiftung, and Advocacy for Neuroacanthocytosis Patients; and has served as an expert witness for German courts of justice in medicolegal cases

The other authors report no conflict of interest
\end{abstract}

Received 14 November 2010 Received in final form 23 February 2011 Accepted 11 March 2011

\section{Análise clínica e genética em 29 pacientes brasileiros com fenótipo doença de Huntington-símile}

\section{RESUMO}

A doença de Huntington (DH) é uma doença neurodegenerativa caracterizada por coréia, alterações comportamentais e demência, causada por uma expansão patológica do trinucleotídeo CAG no gene HTT. Vários pacientes têm sido descritos com o fenótipo típico para a DH porém sem a mutação esperada. O objetivo deste estudo foi avaliar a ocorrência de doenças como doença de Huntington-símile 2 (DHS-2), ataxias espinocerebelares tipo 1, 2, 3 e 17, atrofia dentatorubral-palidoluisiana e coreoacantocitose (CAc) entre 29 pacientes brasileiros com fenótipo doença de Huntingtonsímile. No grupo analisado, encontramos 3 pacientes com DHS-2 e 2 pacientes com CAc. O diagnóstico permaneceu obscuro em 79,3\% dos pacientes. DHS-2 foi a principal causa do fenótipo DH-símile no grupo analisado, provavelmente devido a ancestralidade africana na população brasileira. Entretanto, a etiologia permaneceu indeterminada na maioria dos pacientes avaliados.

Palavras-chave: doença de Huntington, doença de Huntington-símile, coreo-acantocitose, doença de Huntington-símile 2.

'Department of Neuroscience and Behaviour Sciences, Ribeirão Preto School of Medicine, University of São Paulo, Ribeirão Preto SP, Brazil; ${ }^{2}$ Department of Neurology, James J. Peters Veterans Affairs Medical Center, Bronx, and Mount Sinai School of Medicine, New York, USA; ${ }^{3}$ Department of Neurology, Ludwig-Maximilians-Universität, München, Germany; ${ }^{4}$ Department of Genetics and Cytogenetics, Neurogenetics Unit, Hospital Pitié-Salpêtrière, Assistance Publique - Hôpitaux de Paris, France; ${ }^{5}$ Department of Medical Genetics, School of Medical Sciences, University of Campinas (Unicamp), Campinas SP, Brazil. 
Huntington's disease (HD) is a progressive, neurodegenerative disorder characterized by chorea, dystonia or parkinsonism, cognitive impairment and behavioral abnormalities, with typical onset in young adulthood. HD is caused by a pathological expansion of CAG trinucleotide repeats in the HTT gene.

Since the identification of the causative mutation, it has been recognized that a number of patients with the classical HD phenotype have disease due to another etiology. These include prion diseases such as HDL1; autosomal dominant disorders due to inheritance of an expanded trinucleotide repeat sequence, such as HDL2, and DRPLA (dentatorubral-pallidoluysian atrophy); disorders affecting primarily the cerebellum, in which movements disorders can also be seen - FRDA (Friedreich ataxia), SCA (spinocerebellar atrophy) 1, SCA 2, SCA 3 and SCA 17; the neuroacanthocytosis syndromes, chorea-acanthocytosis (ChAc) and McLeod syndrome; and the neurodegeneration with brain iron accumulation (NBIA) syndromes, neuroferritinopathy, aceruloplasminemia and Pantothenate kinase-associated neurodegeneration (PKAN).

There have been several published studies addressing the etiological diagnosis of patients with an HD-like phenotype ${ }^{1-14}$; however, these have been mainly drawn from European and North American populations. We performed a transversal study of the genetic and clinical findings from a group of non-HD HD-like patients who attended a Brazilian movement disorders clinic.

\section{METHOD}

The medical records of 108 patients who were tested for HD between 1998 and 2006, were reviewed. Patients with an HD-like phenotype, defined as a progressive disorder with chorea, dystonia, parkinsonism, ataxia or myoclonus associated with a cognitive, psychiatric or behavioral impairment who did not have a pathological expansion on HTT gene underwent further clinical examination and testing for DRPLA, HDL2, SCA 1, 2, 3, 17 and ChAc. Although a true HD-like phenotype requires autosomal dominant inheritance, we did not use this criterion to select our patients, as an absent family history is non-informative.

DNA analysis of ATN1 (DRPLA), JPH3 (HDL2), ATX1 (SCA1), ATX2 (SCA2), ATX3 (SCA3) and TBP (SCA17) were performed by sizing of fluorescent PCR products encompassing the CTG/CAG expansion site. The PCR products were loaded on 3730 DNA Analyzer or Megabace 1000 (GE) and analyzed using GeneMapper software [AppliedBiosystems] or Fragment Profiler (GE). As the standard PCR protocol does not allow detection of alleles carrying very large expansions as described for the juvenile, severe form of HD, triplet repeat primed $\mathrm{PCR}^{15}$, which permits detection of large expansions, was performed for all patients who were not heterozygous at the HTT locus and/or the JPH3 locus.

Patients who were found to have acanthocytes on peripheral blood smear, elevation of serum CK levels, or evidence of myopathy or peripheral neuropathy, had

Table 1. Clinical and molecular findings in HD and HDL patients.

\begin{tabular}{lccc} 
& HD & HDL & p \\
\hline Number of cases & 37 & 29 & \\
Age of onset & $35.1 \pm 12.8$ & $30.7 \pm 17.6$ & $0.25^{\dagger}$ \\
Male:Female ratio & $16: 21$ & $14: 15$ & $0.68^{\ddagger}$ \\
Chorea & $37(100 \%)$ & $22(75 \%)$ & $0.002^{\#}$ \\
Ataxia & $7(18.9 \%)$ & $8(27.5 \%)$ & $0.40^{\ddagger}$ \\
Myoclonus & 0 & $2(6.8 \%)$ & $0.19^{\#}$ \\
Dystonia* & 0 & $2(6.8 \%)$ & $0.19^{\#}$ \\
Tremor & 0 & $1(3.4 \%)$ & $0.43^{\#}$ \\
Parkinsonism* & 0 & 0 & - \\
Psychiatric disturbance & $17(45.9 \%)$ & $15(51.7 \%)$ & $0.64^{\ddagger}$ \\
Dementia & $25(65.7 \%)$ & $20(68.9 \%)$ & $0.90^{\ddagger}$ \\
Epilepsy & $4(10.8 \%)$ & $4(13.7 \%)$ & $0.72^{\#}$ \\
Familiar history & $34(91.8 \%)$ & $19(65.5 \%)$ & $0.007^{\ddagger}$ \\
& AD:34 & AD: $14(48.2 \%)$ &
\end{tabular}


Table 2. Review of HD-like screening studies.

\begin{tabular}{|c|c|c|c|c|c|}
\hline Year & Reference & Population & No HDL & Evaluation & Results \\
\hline 1998 & 1 & US and UK & 15 & SCA $1,2,3,6$ and DRPLA & 0 \\
\hline 2000 & 2 & $\begin{array}{l}\text { European } \\
\text { (France) }\end{array}$ & 32 & $\begin{array}{c}\text { SCA 1,2,3,6,7, DRPLA } \\
\text { RED test }\end{array}$ & $\begin{array}{l}1 \text { patient with an unknown } \\
\text { CAG expansion }\end{array}$ \\
\hline 2001 & 3 & $\begin{array}{c}\text { American } \\
\text { (African ancestry) }\end{array}$ & 330 & HDL2 & $4 \mathrm{HDL} 2$ \\
\hline 2002 & 4 & $\begin{array}{c}\text { European } \\
\text { (Germany and Austria) }\end{array}$ & 1600 & HDL2 & 0 \\
\hline 2003 & 5 & $\begin{array}{l}\text { European } \\
\text { (France) }\end{array}$ & 252 & $\begin{array}{l}\text { HDL } 1, \text { HDL2, SCA } 17 \\
\text { and DRPLA }\end{array}$ & $\begin{array}{l}\mathrm{HDL} 2=2(3.3 \% \text { of typical cases }) \\
\text { SCA } 17=2(3.3 \% \text { of typical cases })\end{array}$ \\
\hline 2004 & 6 & $\begin{array}{c}\text { European } \\
\text { (Germany and Austria) }\end{array}$ & 1712 & SCA 17 & $9(0.005 \%)$ \\
\hline 2004 & 7 & $\begin{array}{l}\text { (North America } \\
\text { Japan, Mexico) }\end{array}$ & $\begin{array}{l}538 \text { (NA) and } \\
44 \text { (Japan) }\end{array}$ & HDL2 & $\begin{array}{c}\text { North America 6/538 (1.1\%) } \\
\text { Japan 0/44 }\end{array}$ \\
\hline 2004 & 8 & $\begin{array}{l}\text { European } \\
\text { (Italy) }\end{array}$ & 98 & $\begin{array}{l}\text { SCA 17. HDL2 } \\
\text { previously excluded }\end{array}$ & $\begin{array}{l}1 \text { possible case with } \\
43 \text { repetitions }\end{array}$ \\
\hline 2005 & 9 & $\begin{array}{l}\text { European } \\
\text { (Yugoslav) }\end{array}$ & 48 & $\begin{array}{c}\text { HDL1, HDL2, } \\
\text { SCA 1,2,3,17, DRPLA, NFP }\end{array}$ & 0 \\
\hline 2005 & 10 & $\begin{array}{c}\text { African } \\
\text { (South Africa) }\end{array}$ & 50 & HDL2 & $15(30 \%)$ \\
\hline 2006 & 11 & $\begin{array}{l}\text { European } \\
\text { (Portugal) }\end{array}$ & 107 & $\begin{array}{l}\text { HDL1, HDL2, SCA 17, } \\
\text { DRPLA, NFP }\end{array}$ & 0 \\
\hline 2008 & 12 & $\begin{array}{l}\text { European } \\
\text { (Spain) }\end{array}$ & 95 & FXTAS & $1(1.6 \%)$ \\
\hline 2008 & 13 & $\begin{array}{l}\text { European } \\
\quad(U K)\end{array}$ & 285 & $\begin{array}{c}\text { HDL1, HDL2, } \\
\text { SCA 1,2,3,17, DRPLA, } \\
\text { NFP, FRDA }\end{array}$ & $\begin{array}{l}\text { SCA } 17=5(1.8 \%) \\
\text { HDL1 }=1(0.4 \%) \\
\text { FRDA }=1(0.4 \%) \\
\text { HDL2 }=1(0.4 \%)\end{array}$ \\
\hline 2008 & 14 & $\begin{array}{l}\text { European } \\
\text { (Polish) }\end{array}$ & 224 & HDL2, SCA17, DRPLA & SCA $17=1(0.44 \%)$ \\
\hline 2011 & & Brazilian & 29 & $\begin{array}{l}\text { HDL2, SCA 1,2,3,17, } \\
\text { DRPLA, ChAC }\end{array}$ & $\begin{array}{c}\mathrm{HDL} 2=3(10.3 \%) \\
\mathrm{ChAc}=2(6.8 \%)\end{array}$ \\
\hline
\end{tabular}

HDL: Huntington's disease-like; DRPLA: dentatorubral-pallidoluysian atrophy; FRDA: Friedreich ataxia; SCA: spinocerebellar atrophy; ChAc: choreaacanthocytosis; NFP: neuroferritinopathy; FXTAS: Fragile X-associated tremor/ataxia syndrome; RED: repeat expansion detection technique.

chorein levels in peripheral blood qualitatively analyzed by Western $\operatorname{blot}^{16}(\mathrm{n}=2)$.

Statistical analysis was performed with SPSS version 10.0 (SPSS, Inc., Chicago, IL, USA). This study was approved by the ethical board of the Hospital das Clínicas de Ribeirão Preto and all patients have signed an informed consent.

\section{RESULTS}

Of the 108 patients tested for HD, seven were excluded due to insufficient data in their medical records. From the remaining subjects, 37 were diagnosed with HD, 35 were not classified as having an HD-like phenotype, and 29 were classified as a HD-like phenotype. As a result, considering the patients with a typical or compatible HD phenotype, we found 29/66 patients (43\%) without pathological CAG expansion on HTT gene.

Table 1 summarizes the main clinical features of HD and HD-like patients. MRI exams were performed in 24 patients and brain $\mathrm{CT}$ in 3 . The most common finding was brain atrophy in $23(85 \%)$ patients. We found no evidence of iron deposition on those patients who underwent MRI exams. All $29 \mathrm{HDL}$ patients had their DNA analyzed for trinucleotide repeat expansions of $H T T$, JPH3, ATX1, ATX2, ATX3, TBP and ATN1. Two patients met criteria for chorein testing and had absent or markedly reduced levels in peripheral blood. From these tests, we diagnosed $3(10.3 \%)$ cases of HDL2 and $2(6.8 \%)$ 
cases of ChAc. The patients with HDL2 were clinically indistinguishable from those with typical HD phenotype. However, patients with ChAc presented clear clinical differences as absence of autosomal dominant history, presence of peripheral involvement and epilepsy in both cases. The patients with HDL2 and ChAc have been previously reported in detail elsewhere ${ }^{17,18}$.

One patient of this study was a deceased sister of one ChAc patient, who presented with chorea and cognitive abnormalities, but whose diagnosis could not be confirmed by Western blot due to the non-availability of required biomaterial. The remaining 23 (79.3\%) patients tested negative for HD, HDL2, SCA1, 2, 3, 17, and DRPLA.

\section{DISCUSSION}

This is the first study to address the diagnosis of diseases responsible for the HD-phenotype in Brazilian patients. Compared with previous studies (Table 2), we found a higher frequency of ChAc and HDL2 among our patients. Considering the 3 unrelated HDL2 cases reported here, together with the patients reported by Teive et al. ${ }^{19}$ and Santos et al. ${ }^{20}$, it is possible that HDL2 is the most common cause of HD-like phenotype in Brazil. A probable explanation is that $44 \%$ of Brazilian population is of African descent ${ }^{21}$, even though this ancestry may be occult ${ }^{19,20}$. This regional difference contrasts with the article of Wild and colleagues ${ }^{13}$, in which SCA 17 was considered the most important cause of the HD-like phenotype in patients from the UK.

Based upon previous studies, we initially decided to test for disorders whose frequencies were higher than $0.5 \%$ of all HD phenocopies. Consequently, we included SCA 17 and HDL2 and excluded HDL1 and FRDA ${ }^{13}$. We have not included neuroferritinopathy because it appears to be even rarer in HD-like patients, with a very small number of families being reported to date, and it is unlikely to occur in patients without evidence of iron deposition in the basal ganglia on MRI ${ }^{22}$.

Screening for ChAc was performed as the clinical characteristics of our patients suggested the diagnosis. It was important to include the investigation for ChAc because Brazil represents the largest population of Japanese and descendants outside Japan ${ }^{21}$, and ChAc appears to be particularly prevalent in Japanese subjects ${ }^{23}$. DRPLA was included for the same reason. In addition, studies have demonstrated that the number of DRPLA cases in non-Asian populations may be higher than previously considered ${ }^{24,25}$. Finally, chorea has been reported as an occasional non-ataxic symptom on SCAs, occurring in approximately $7 \%$ of SCA 1 and 2 and 10\% of SCA 3 patients ${ }^{26}$.

Our data showed that almost $43 \%$ of the patients who had a phenotype compatible with HD tested negative for CAG expansions at the HTT gene. This data diverges from reference studies in this field, which suggest that the frequency of HD-like phenocopies is about 1\% of HD cases $^{27,28}$. We believe that this discrepancy cannot be addressed only as an ascertainment bias, because our sample was selected based on restrictive criteria. In addition, other studies have found proportions of HD-like patients in $33 \%{ }^{10}, 35.5 \%{ }^{11}$, and $36.3 \%{ }^{9}$ of their study populations. Krause and colleagues ${ }^{10}$ provided an insight in this problem, showing that, in their population, only $16 \%$ of white patients were HD phenocopies, in contrast to $64 \%$ of the black patients. Therefore, the percentage of HD-like patients may differ according to the ethnicity of the study population.

Our clinical data shows that the absence of an autosomal-dominant history and signs of peripheral involvement or seizures may help differentiate between ChAc and HD. Although the presence of acanthocytes may improve the diagnostic accuracy, their absence does not rule out the diagnosis of $\mathrm{ChAc}^{29}$. In addition to screening for acanthocytes, we considered the diagnosis of ChAc in patients with elevated CK levels and clinical signs of myopathy or peripheral neuropathy.

The patients with HDL2 were clinically very similar to the classical HD phenotype, and this diagnosis should be suspected in the presence of typical HD phenotype with absent HTT mutation, especially if an autosomal dominant inheritance and African ancestry is present.

However, this survey has some limitations. First, the small number of patients identified as having an HD-like phenotype, what can be explained by the rarity of these disorders and because we have enrolled patients from only one clinical center. Second, referral bias is unavoidable when including patients from a referral movement disorders clinic, therefore, it is possible that the relative frequency of HD-like disorders was overestimated. Third, in spite of screening systematically for seven diseases, $79.3 \%$ of our patients remained undiagnosed, confirming a considerable etiologic heterogeneity among HD-like disorders and indicate the need for additional studies, using a broader panel of diagnostic tests. Considering the discrepancy between the high percentage of cryptic cases and the rareness of the remaining diseases to be tested for, it is likely that among the HD-like phenotypes some causalities have not been described yet.

\section{REFERENCES}

1. Rosenblatt A, Ranen NG, Rubinsztein DC, et al. Patients with features similar to Huntington's disease, without CAG expansion in huntingtin. Neurology 1998;51:215-220.

2. Vuillaume I, Meynieu P, Schraen-Maschke S, Destée A, Sablonnière B. Absence of unidentified CAG repeat expansion in patients with Huntington's disease-like phenotype. J Neurol Neurosurg Psychiatry 2000;68: 672-675. 
3. Holmes SE, O'Hearn E, Rosenblatt A, et al. A repeat expansion in the gene encoding junctophilin-3 is associated with Huntington disease-like 2. Nat Genet 2001:4:377-378.

4. Bauer I, Gencik M, Laccone F, et al. Trinucleotide repeat expansions in the junctophilin-3 gene are not found in Caucasian patients with a Huntington's disease-like phenotype. Ann Neurol 2002;51:662.

5. Stevanin G, Fujigasaki H, Lebre AS, et al. Huntington's disease-like phenotype due to trinucleotide repeat expansions in the TBP and JPH3 genes. Brain 2003;126:1599-1603.

6. Bauer P, Laccone F, Rolfs A, et al. Trinucleotide repeat expansion in SCA17/ TBP in white patients with Huntington's disease-like phenotype. J Med Genet 2004;41:230-232.

7. Margolis RL, Holmes SE, Rosenblatt A, et al. Huntington's disease-like 2 (HDL2) in North America and Japan. Ann Neurol 2004;56:670-674.

8. Cellini E, Forleo P, Nacmias B, et al. Spinocerebellar ataxia type 17 repeat in patients with Huntington's disease-like and ataxia. Ann Neurol 2004;56:163.

9. Keckarević M, Savić D, Svetel M, Kostić V, Vukosavić S, Romac S. Yugoslav HD phenocopies analyzed on the presence of mutations in PrP, ferritin, and Jp-3 genes. Int J Neurosci 2005;115:299-301.

10. Krause A, Hetem C, Holmes SE, Margolis RL. HDL2 mutations are an important cause of Huntington's disease in patients with African ancestry [abstract \#A17]. J Neurol Neurosurg Psychiatr 2005;76(Suppl 4):S17.

11. Costa MC, Teixeira-Castro A, Constante M, et al. Exclusion of mutations in the PRNP, JPH3, TBP, ATN1, CREBBP, POU3F2 and FTL genes as a cause of disease in Portuguese patients with a Huntington-like phenotype. J Hum Genet 2006;51:645-651.

12. Rodriguez-Revenga $L$, Santos MM, Sánchez A, et al. Screening for FXTAS in 95 Spanish patients negative for Huntington disease. Genet Test 2008; 12:135-138.

13. Wild EJ, Mudanohwo EE, Sweeney MG, et al. Huntington's disease phenocopies are clinically and genetically heterogeneous. Mov Disord 2008;23: 716-720.

14. Sułek-Piatkowska A, Krysa W, Zdzienicka E, et al. Searching for mutation in the JPH3, ATN1 and TBP genes in Polish patients suspected of Huntington's disease and without mutation in the IT15 gene. Neurol Neurochir Pol 2008;42:203-209.

15. Warner JP, Barron LH, Goudie D, et al. A general method for the detection of large CAG repeat expansions by fluorescent PCR. J Med Genet 1996; 33:1022-1026.
16. Dobson-Stone C, Velayos-Baeza A, Filippone LA, et al. Chorein detection for the diagnosis of chorea-acanthocytosis. Ann Neurol 2004;56:299-302.

17. Rodrigues GR, Walker RH, Bader B, Danek A, Marques W Jr, Tumas V. Chorea-acanthocytosis: report of two Brazilian cases. Mov Disord 2008;23: 2090-2093.

18. Rodrigues GR, Walker RH, Brice A, et al. Huntington's disease-like 2 in Brazil: report of 4 patients. Mov Disord 2008;23:2244-2255.

19. Teive HAG, Becker N, Munhoz RP, et al. Huntington's disease-like 2: the first case report in Latin America in a patient without African ethnic origin. Mov Disord 2007;22(Suppl 16):S27.

20. Santos C, Wanderley H, Vedolin L, Pena SD, Jardim L, Sequeiros J. Huntington disease-like 2: the first patient with apparent European ancestry. Clin Genet 2008;73:480-485.

21. IBGE. Características gerais da população: censo demográfico 2000. Rio de Janeiro, Brasil. 2003:37-48.

22. McNeill A, Birchall D, Hayflick SJ, et al. T2* and FSE MRI distinguishes four subtypes of neurodegeneration with brain iron accumulation. Neurology 2008;70:1614-1619.

23. Hirose G. Neuroacanthocytosis in Japan: review of the literature and cases. In: Walker RH, Saiki S, Danek A (Eds). Neuro-acanthocytosis syndromes II. Berlin: Springer; 2008:75-86.

24. Martins S, Matamá T, Guimarães L, et al. Portuguese families with dentatorubropallidoluysian atrophy (DRPLA) share a common haplotype of Asian origin. Eur J Hum Genet 2003:808-811.

25. Wardle M, Majounie E, Williams NM, Rosser AE, Morris HR, Robertson NP. Dentatorubral pallidoluysian atrophy in South Wales. J Neurol Neurosurg Psychiatry 2008;79:804-807.

26. Schmitz-Hübsch T, Coudert M, Bauer $P$, et al. Spinocerebellar ataxia types 1, 2, 3, and 6: disease severity and nonataxia symptoms. Neurology 2008; 71:982-989.

27. Kremer B, Goldberg P, Andrew SE, et al. A worldwide study of the Huntington's disease mutation. The sensitivity and pecificity of measuring CAG repeats. N Engl J Med 1994;330:1401-1406.

28. Andrew SE, Goldberg YP, Kremer B, et al. Huntington disease without CAG expansion: phenocopies or errors in assignment? Am J Hum Genet 1994;54:852-863.

29. Bayreuther C, Bayreuther C, Borg M, Ferrero-Vacher C, Chaussenot A, Lebrun C. Chorea-acanthocytosis without acanthocytes. Rev Neurol (Paris) 2010; 166:100-103. 